\title{
Wildlife Protection and Prevention of Illegal Wildlife Trade: Legal Framework and Challenges
}

\author{
By Gloria Kembabazi*
}

\begin{abstract}
This paper examines wildlife protection and prevention of illegal wildlife trade, the importance of it and the role law plays in ensuring that wildlife is protected and its illegal trade curbed. It goes further to examine some national, regional, and international instruments towards these double aims. The national instruments focus on Uganda and the regional instruments focus on the East African Community. Towards the end, the author also examines and analyses some challenges facing wildlife protection and prevention of illegal wildlife trade.
\end{abstract}

\section{A. INTRODUCTION}

The first step towards understanding why wildlife protection and prevention of illegal wildlife is crucial is to understand why. Protecting wildlife is part of our human responsibility to the earth. Wildlife refers to both the fauna and flora of the planet that are not in the direct control of human beings. ${ }^{1}$ The earth is collectively composed of all of the wildlife, other plants and animals as well as us human beings. It is the activities of humans that greatly impact the survival of other species and this is why it is especially important to ensure that wildlife is protected from those of our activities that may be harmful to it. For instance, according to World Wide Fund for Nature (WWF), human activity is by far the biggest cause of habitat loss - one of the key dangers to wildlife. ${ }^{2}$

\section{Rationale for Protecting Wildlife and Preventing Illegal Wildlife Trade}

Moreover, as the more intelligent beings we ought to ensure that we are good stewards of the rest of the life on earth and particularly wildlife. Good stewardship encompasses protection of wildlife and this in turn can include may activities such as conservation. Biodiversity maintenance and preservation is one of the biggest goals of wildlife protection

* The author is a Ugandan lawyer with a specialisation in regional integration law. She holds an LLB (UCU), PgDLP (LDC), and LLM (UDSM). She can be reached on glorinice@yahoo.com.

1 European Environment Agency, Wildlife, https://www.eea.europa.eu/help/glossary/eea-glossary/wil dlife accessed on 1st Dec 2021.

2 World Wide Fund for Nature (WWF) Fact Sheet, What Impacts do Human Activities Have on Habitats and Wildlife May 2017. 
and prevention of illegal wildlife trade. When there is no deliberate goal towards these two targets, we risk extinction of some species.

Protection of wildlife and prevention of illegal wildlife trade is also closely linked to environmental protection more generally. Sometimes the measures to achieve either one of these aspects ensure the attainment of the other. For instance, when the environment is protected, we preserve the natural habitats of wildlife and thus protect the wildlife by ensuring its livelihood is safe and remains optimum for their survival. This is especially important to pay attention to as it is estimated that about $177,000 \mathrm{Km}^{2}$ of forests are cleared every year. What must always be remembered is that protection of wildlife is not a token we give to wildlife but it is also for our own safety, survival, and wellbeing. The life on the planet earth is in symbiosis with each other.

Relatedly, we must also respect animal rights, not only for those animals we consider our pets or otherwise domestically beneficial but also to those we categorise as wildlife. This is especially important as the contrary to wildlife protection and illegal trade is often in the form of poaching. Poaching as it is by nature illegal is very often dangerous to the animals and their wellbeing as well as survival. Where the poached animals are not completely killed, they suffer injury, trauma and other debilitation from the effects of the poaching activities. A study on long term effects of poaching revealed the negative effects of poaching on other elephants bonded to that animal as well as residual effects to the greater elephant community and a lowering of survival rates among orphaned ones. ${ }^{3}$

The threat to wildlife particularly the threat of poaching often comes about because of the wildlife commodities certain people may wish to obtain. It is a multibillion-dollar industry. ${ }^{4}$ Examples of wildlife commodities include: ivory tusk, rhino horns, live birds or reptiles, reptile scales, skins and leathers, and food. One can see that from these examples whole wildlife can be hunted such as in obtaining birds, leathers or food and not just parts of it. Where parts of animals are taken then one can see that this can leave the animal severely injured or disabled such as in the case of obtaining tusks, horns and scales.

The value of environmental crime is estimated at USD 258 billion. ${ }^{5}$ There are many reasons given as to why people hunt, poach or trade wildlife and or its commodities. These reasons include for its decorative, medicinal, or edible elements. This of course does not justify illegal, harmful or unsustainable practices. While some arguments for why may seem beneficial there are also many considerations as to what the determining factor should be when it comes to aspects of purely recreational motives or questions on whether

3 Jane Wynyard, Studying Longer-term Effects on Elephants from Poaching https://phys.org/news/20 21-09-longer-term-effects-elephants-poaching.html Colorado State University, (accessed Sept 30th 2021).

4 United Nations Office on Drugs and Crime (UNODC), World Wildlife Crime Report: Trafficking in Protected Species, United Nations, New York, 2020.

5 Jee Y. Geronimo, Value of Environmental Crime at Record-High of USD 258 - Report 2016, https:/ /www.rappler.com/science/135278-environmental-crime-unep-interpol-report/ (accessed Sept $25^{\text {th }}$ 2021). 
alternatives to the sought-after commodities exist or whether a more sustainable approach exists or even less harmful methods of extraction.

\section{B. WHAT ROLE DOES LAW HAVE?}

Accountability apportioning is one of the biggest roles that law plays in its regulatory and enforcement capacities. Law creates responsibility for its intended subjects. This ensures that people know what they are supposed to do and what they are not supposed to do as well as how they can be held accountable on the later instance. Law increases the risk of heavy punishments. This is also known as the deterrence purpose and serves to deter impugned behaviour. This is especially in the case of poaching and illegal trade where those who participate in such activities can be held accountable to the fullest extent possible under law.

Awareness about rights and duties is also a distinct role that law plays in ensuring that those who seek to find information on what is proper to do or what is forbidden is clear to all involved or those who may seek to find out. With legal backing, the work and message of activists and other wildlife campaigners is lent credibility and seriousness. Law is one of the tools that can be used to achieve conservation objectives. ${ }^{6}$

Relationship between laws and policy is also critical and that means that laws can be a driving factor for the evolution of policy and vice versa. Whereas policies take on the voice of generalised statements, laws are specific and certain. ${ }^{7}$ This quality of certainty that law has ensures that the important matters are set in stone, so to speak, for everyone to have the clarity of what is the required standard of action. An example of certainty is that through laws certain areas can be clearly designated as protected areas hence also creating certainty.

Law also brings in strong tools to make it coercive towards ensuring the desired behaviour is achieved or maintained. One of the tools is the fact that law empowers law enforcement to actually enforce the law. For instance, international wildlife law enables the increased cooperation among and between government and non-governmental stakeholders. ${ }^{8}$

The criminal justice system is also a very important tool of law. Criminal justice ensures that due process is followed to enforce rights but also to hold accountable perpetrators as well as enforce the deterrence goal of certain legal provisions as regards punishment. In terms of wildlife there may also be a retributive factor where certain actions affect not only the wildlife but the communities depending on or living in symbiosis with the wildlife.

6 Arie Trouwborst, Andrew Blackmore, Luigi Boitani et al., International Wildlife Law: Understanding and Enhancing its Role in Conservation, Bio Sciencem Volume 67, Issue 9, September 2017, Pages 784-790, https://academic.oup.com/bioscience/article/67/9/784/4077046 (accessed Sept $25^{\text {th }}$ 2021).

7 Nixon Sifuna, Use of Law in Wildlife Management, Beijing Law Review, Vol.12 No.3, September $2021 \mathrm{https}: / /$ scirp.org/journal/paperinformation.aspx?paperid=112144 (accessed Sept $\left.25^{\text {th }} 2021\right)$.

8 Ibid., No. 6. 


\section{LEGAL FRAMEWORK RELEVANT TO WILDLIFE}

Tracing the history of law and wildlife takes us back to antiquity. The first identified forestry conservation laws were identified in Babylon dating to 1900BC. ${ }^{9}$ A law for the establishment of nature reserves has also been identified as having been promulgated in Egypt in 1370 BC. ${ }^{10}$ This section of the paper will focus on Ugandan laws, East African Community Laws and then look at the international legal frameworks. The latter is only a recently emerged phenomenon of the last quarter of the 19th Century.

\section{Ugandan Legal Framework}

Uganda has a long history of wildlife management and conservation. The earliest such national effort can be traced to the 1923 Elephant Control Department. In Uganda some current examples of laws relevant to this subject are as follows:

The Uganda Wildlife Act, $2019^{11}$ provides for the conservation and sustainable management of wildlife, strengthening of wildlife conservation and management, continuance of the Uganda Wildlife Authority and streamlining the roles and responsibilities of institutions involved in wildlife conservation and management. It specifically provides for the use of wildlife resources. ${ }^{12}$ This is to ensure that intended annual harvest does not exceed the sustainable yield level.

It further provides for the historic rights of communities around conservation areas. ${ }^{13}$ This covers aspects such as access to resources that are crucial to the survival of such communities, studying, identifying and protecting cultural interest of such a community and also provides for the possibility of acquiring land in a protected areas where private ownership is contrary to the sustainable management of wildlife.

The Act also provides for the declaration of protected species. ${ }^{14}$ This is to ensure that the conservation status is clear and works towards protecting wildlife as well as preventing illegal wildlife trade of such wildlife or their commodities.

The Act provides for types of wildlife use rights. ${ }^{15}$ Such rights can include hunting, farming, ranching, trading, use for education or scientific purposes such as medicinal

9 Michael Bowman, Peter Davies, and Catherine Redgwell, The Historical Evolution of International Wildlife Law, $5^{\text {th }}$ July 2011, https://www.cambridge.org/core/books/abs/lysters-international-wil dlife-law/historical-evolution-of-international-wildlife-law/3165CE596915955956509E8F0327E8 27 (accessed September 28th 2021).

10 Ibid.

11 The Uganda Wildlife Act, 2019, Acts Supplement No.10, Act 17 of 2019, $27^{\text {th }}$ September, 2019.

12 Ibid., Uganda Wildlife Act, Section 31.

13 Ibid., Section 32.

14 Ibid., Section 34.

15 Ibid., Section 35. 
experiments and developments, community resource access, use as pets or ornaments, and tourism and recreation. The Act also provides for professional hunters and trappers. ${ }^{16}$

The Act also tackles international trade in species and specimens. ${ }^{17}$ It specifically provides for import, export or re-export permit with provisions also covering additional restriction on import, export, transit or re-export of specimen. ${ }^{18}$

Some of the more salient provisions are the following: the Act, as any good law provides for penalties, forfeitures and other legal proceedings. ${ }^{19}$ It also contains provisions for conventions and treaties on wildlife management. More on this will be discussed under the international legal framework. ${ }^{20}$

The National Environment Act, $2019^{21}$ is also of relevance to wildlife protection and prevention of illegal wildlife trade. It establishes the National Environmental Management Agency (NEMA) which is an agency responsible for managing the environment through coordinating, monitoring, regulating, and supervising all activities in the environment. ${ }^{22}$

The relevant provisions in this Act include the provisions on declaration of special conservation areas, ${ }^{23}$ restriction on the use of lakes and rivers, ${ }^{24}$ protection of riverbanks, lakeshores and natural beaches, ${ }^{25}$ provisions on the conservation of biological diversity, biological resources in situ and ex situ. ${ }^{26}$

\section{Regional Legal Frameworks}

Under the East African Community Treaty, ${ }^{27}$ Partner States undertake to develop a collective and coordinated policy for the conservation and sustainable utilisation of wildlife and other tourist sites in the community. ${ }^{28}$ This covers the harmonisation of policies for conservation of wildlife within and outside protected areas, exchanging information, adopt common policies and coordinating efforts in controlling and monitoring encroachment and poaching activities.

16 Ibid., Section 51.

17 Ibid., Part X, Section 62.

18 Ibid., Section $62 \& 63$.

19 Ibid., Part IX.

20 Ibid., Section 86.

21 The National Environment Act, 2019, Acts Supplement No.2 Act No.5 of 2019, $7^{\text {th }}$ March 2019.

22 Ibid., National Environment Act, Section 8.

23 Ibid., Section 51.

24 Ibid., Section 52.

25 Ibid., Section 53.

26 Ibid., Section 59, 60, 61.

27 Treaty for the Establishment of the East African Community, 1999.

28 Ibid., Article 116. 
The East African Community Customs Management Act, 2004 is also crucial for prevention of exports that are prohibited which include many wildlife commodities. ${ }^{29}$

Some activities towards these aims include the creation of Regional Wildlife Conservation Information System. ${ }^{30}$ There also exists a Strategic Plan of Wildlife Management and some notable civil society players such as the East Africa Wildlife Society (EAWLS). ${ }^{31}$

\section{International Legal Frameworks}

At the international level, international wildlife law is contained in 5 global instruments that will be explained in detail below as well as some others that are deemed of relevance. Some of the international conventions relevant to protection of wildlife and prevention of illegal wildlife trade are as follows:

Convention on International Trade in Endangered Species (CITES) ${ }^{32}$ establishes protection for over 35,000 species of plants and animals in relation of international wildlife trade. It specifically regulates the trade in listed specimens of species.

The Convention on Migratory Species $(\mathrm{CMS})^{33}$ provides for the identification and conservation of such species as well as the international co-operation toward such action.

The Convention on Biological Diversity (CBD) is another international framework towards wildlife protection. It covers the whole ecosystem and hence works to protect both habitat and wildlife as well as promoting sustainable use. ${ }^{34}$

The Convention on Wetlands of International Importance also ensures the protection of wildlife habitats therefore protecting the wildlife, especially as it protects waterfowl habitat as well as generally protects the eco-system diversity. ${ }^{35}$

The UNESCO Convention Concerning the Protection of the World Cultural and Natural Heritage works towards global conservation efforts by identifying and protecting the world's natural and cultural heritage considered to be of outstanding universal value, particularly including habitats of threatened species of animals and plants ${ }^{36}$

29 The East African Community Customs Management Act, 2004, $2^{\text {nd }}$ Schedule Part B.

30 East African Community, Wildlife Management, https://www.eac.int/tourism/wildlife-management (accessed October 16 ${ }^{\text {th }}$ 2021).

31 The East African Wildlife Society, https://eawildlife.org/our-history/ (accessed December $3^{\text {rd }}$ 2021).

32 Convention on International Trade in Endangered Species of Wild Fauna and Flora (CITES) Signed at Washington D.C. on $3^{\text {rd }}$ March 1973, Article III, IV, \& V.

33 Convention on the Conservation of Migratory Species of Wild Animals (CMS) 1979, Article V.

34 Convention on Biological Diversity (CBD), 1992, Article 1, 7, 8, 9, \& 10.

35 Convention on Wetlands of International Importance, 1971, aka, Ramsar Convention, Article 4 \& 8.

36 UNESCO Convention Concerning the Protection of the World Cultural and Natural Heritage, 1972, Article 2 Para 2. 
UN Convention Against Corruption (UNCAC) ${ }^{37}$ is also critical to wildlife protection as it ensures that corruption is curtailed. A lot of the illegal wildlife trade is possible due to corruption and it has been noted that addressing corruption is foundational to preventing wildlife crime as corruption exists across all stages of the wildlife supply chain and can facilitate the illegal trade of wildlife. ${ }^{38}$

UN Convention on Transnational Organised Crime (UNTOC), 2000, is also relevant to prevention of illegal wildlife trade as it works to curtail the trade links for wildlife commodities. In Uganda, particularly wildlife trade is a source of funds for arms trafficking in the greater region. ${ }^{39}$

\section{CHALLENGES}

There are certain challenges to the protection of wildlife and the prevention of illegal wildlife trade. Here below some of them are expounded:

There are implementation bottlenecks and hindrances. This means that sometimes laws maybe in place but the implementation may not be so straight forward or in reality as it exists on paper. Laxity of law enforcement has been cited as one of the challenges. ${ }^{40}$

Inadequate personnel are also a challenge to protection of wildlife and the prevention of illegal wildlife trade. Personnel required for laws relating to wildlife may include game rangers, supervisors, court staff and even government officials. This kind of personnel may be in shortage due to the nature of the work that is required to protect wildlife and also to prevent illegal wildlife trade. For instance, game rangers may be required in large numbers to effectively patrol a game park of several square kilometres.

Access can also be a challenge to wildlife protection and prevention of illegal trade. This can be in the form of difficult to navigate terrain or remoteness of some wildlife reserves for instance. In the specific matter of prevention of illegal wildlife trade, it maybe that such trading happens in secretive places that are not easily known or accessible to law enforcement for instance.

Scanty awareness about the need and how to protect wildlife is also a challenge. As discussed previously some wildlife commodities are to meet basic needs such as food. This means that in some instances those who participate in poaching or other harmful acts towards wildlife are only looking to survive and are not aware of alternative or sustainable

37 UN Convention Against Corruption (UNCAC), 2004, Article 7, 8, 12, 13, 14 etc.

38 United Nations Office on Drugs and Crime (UNODC), Wildlife Crime Report, Trafficking in Protected Species, https://www.unodc.org/documents/data-and-analysis/wildlife/2020/World_Wild life_Report_2020_9 July.pdf (accessed Dec 3rd 2021) Pg. 20.

39 Ibid., Pg. 250.

40 DLA Piper, Empty Threat: Does the Law Combat Illegal Wildlife Trade: An Eleven-Country Review of Legislative and Judicial Approaches, Pg. 234. 
options or methods such as conservation. This has been the case where poachers are handed light sentences despite guilt due to such mitigating factors. ${ }^{41}$

The continued availability of markets for wildlife is one of the driving factors for the prevalence of harming wildlife illegal wildlife trade.

Trafficking rings also make it harder for the law of catch-up with them. They create systems that hide the players in the illegal wildlife chain of activities. For instance, while there is no illegal ivory trade in Uganda, the country is used as a transit country by poachers from neighbouring countries. ${ }^{42}$

International nature of most game parks vis a vis artificial boarders and cross border enforcement challenges is another factor to consider. This is a challenge in that game rangers for instance are not automatically able to patrol across borders and neither is law enforcement easy to curb cross boarder perpetrators of wildlife crimes.

Parks with human beings are also a challenge in that it must be a balancing act between human livelihood and protection of wildlife. Some of these communities have had close relationships with the wildlife in the communities they live and hence some of their activities may seem criminal from the outside when they are simply ensuring their own survival.

Another challenge is the amusement factor. Animals are sometimes seen for their amusement/entertainment value and consequently taken out of their natural habitats. Unfortunately, this stress them so much even to infertility not to mention several other health problems.

Illicit captive breeding schemes are also part of the challenge to protecting wildlife. A lot of animals are captured and bred illegally which can destabilise not only them but also displace and distabilise the ecosystem. For instance, the Pablo rhinos in South America.

Laundering of illegal wildlife trade products makes it harder to trace illegal wildlife trade. Laundering hides sources, chains of transport and beneficiaries thus creating a circumstance of smokes and mirrors where authorities are not able to hold those responsible accountable.

In conclusion, wildlife protection and prevention of illegal wildlife trade is crucial to protecting the ecosystem by preserving our biodiversity. It is also important to ensure the protection of animal rights as these activities often harm the animals and violate animal rights. Law is a great tool towards attaining this goal but so is policy and implementation. Moreover, one must always keep in mind that this calls for a concerted effort by all stakeholders to ensure that wildlife is protected and illegal wildlife trade is curbed and curtailed. 